
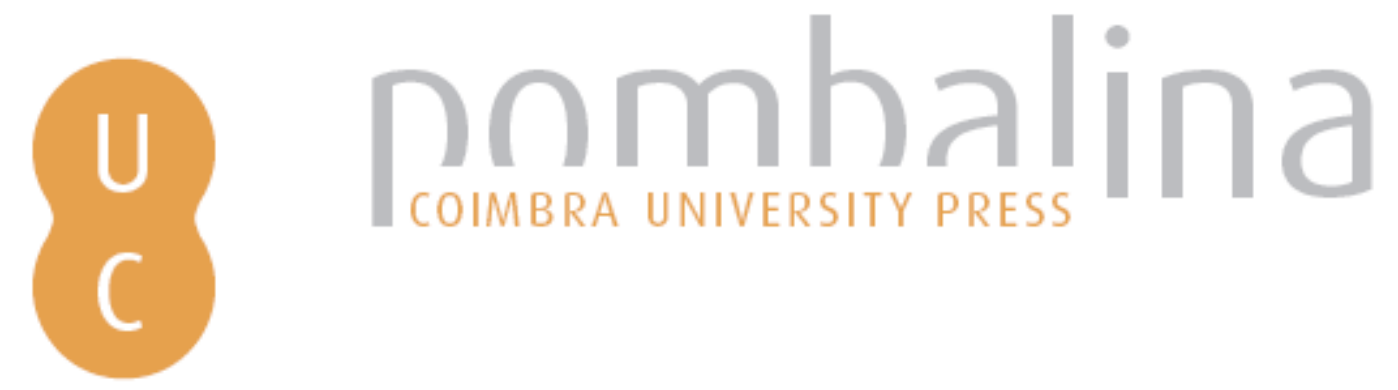

\title{
Why is the distance between what we know and what we don't know always beyond of what we can achieve with our velocity of learning?
}

\author{
Autor(es): $\quad$ Rodrigues, Nuno Álvaro Ferreira; Kovacec, Alexander; Almeida, Ana \\ Cristina Ferreira de
}

Publicado por: Imprensa da Universidade de Coimbra

URL persistente:

URI:http://hdl.handle.net/10316.2/38626

DOI:

DOI:http://dx.doi.org/10.14195/978-989-26-0775-7_22

Accessed : $\quad$ 26-Apr-2023 12:52:02

A navegação consulta e descarregamento dos títulos inseridos nas Bibliotecas Digitais UC Digitalis, UC Pombalina e UC Impactum, pressupõem a aceitação plena e sem reservas dos Termos e Condições de Uso destas Bibliotecas Digitais, disponíveis em https://digitalis.uc.pt/pt-pt/termos.

Conforme exposto nos referidos Termos e Condições de Uso, o descarregamento de títulos de acesso restrito requer uma licença válida de autorização devendo o utilizador aceder ao(s) documento(s) a partir de um endereço de IP da instituição detentora da supramencionada licença.

Ao utilizador é apenas permitido o descarregamento para uso pessoal, pelo que o emprego do(s) título(s) descarregado(s) para outro fim, designadamente comercial, carece de autorização do respetivo autor ou editor da obra.

Na medida em que todas as obras da UC Digitalis se encontram protegidas pelo Código do Direito de Autor e Direitos Conexos e demais legislação aplicável, toda a cópia, parcial ou total, deste documento, nos casos em que é legalmente admitida, deverá conter ou fazer-se acompanhar por este aviso.

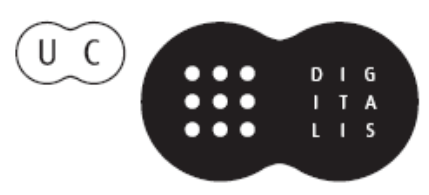




\section{INTERNATIONAL \\ STUDIES IN TIME \\ PERSPECTIVE}

MARIA PAULA PAIXÃO

JOSÉ TOMÁS DA SILVA

(COORD.)

VICTOR ORTUÑO

PEDRO CORDEIRO

(EDITORS)

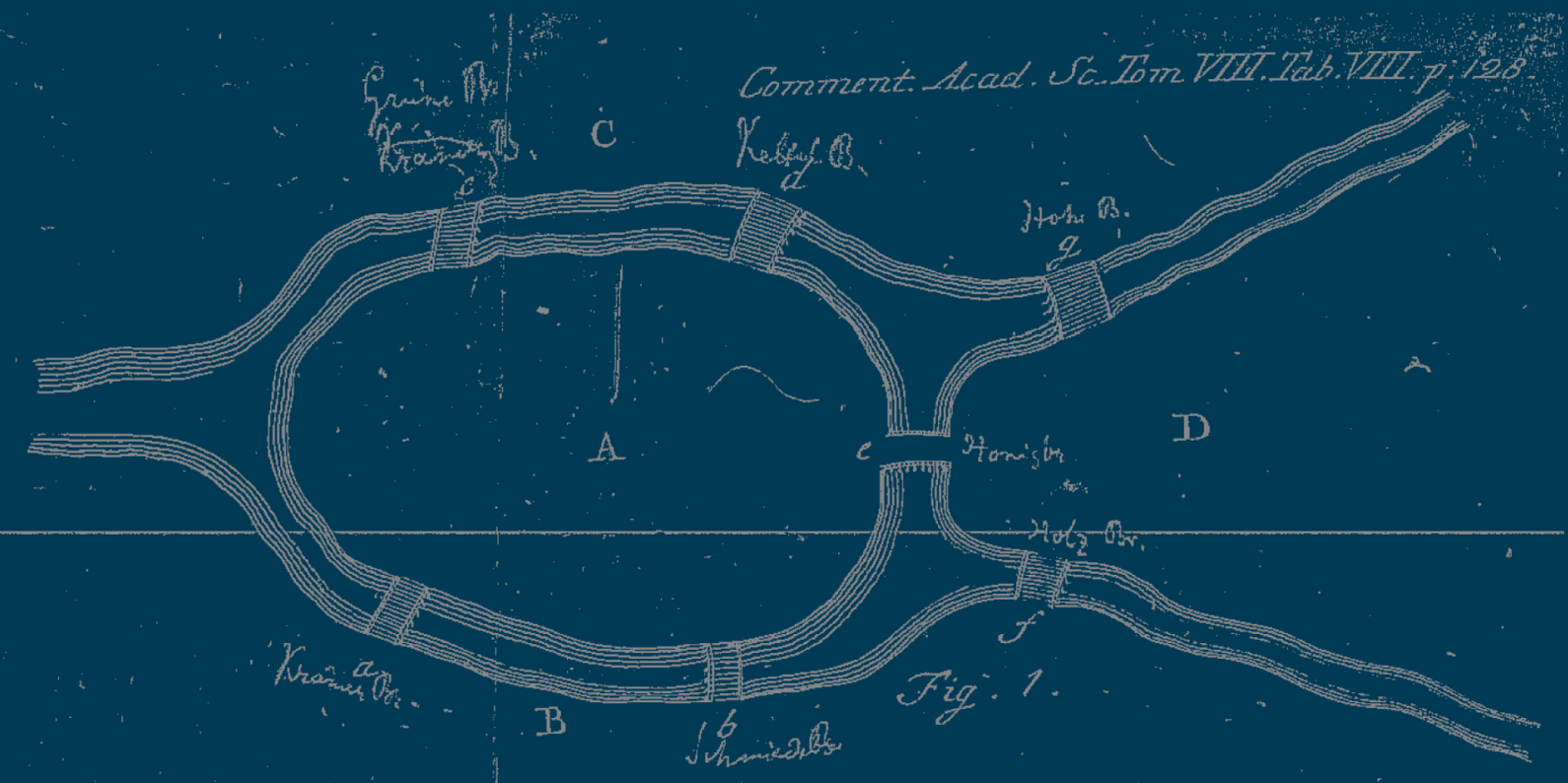

IMPRENSA DA

UNIVERSIDADE

DE COIMBRA

COIMBRA

UNIVERSITY

PRESS 


\title{
Chapter 22 \\ WHY IS THE DISTANCE BETWEEN WHAT WE KNOW AND WHAT WE DON'T KNOW ALWAYS BEYOND OF WHAT WE CAN ACHIEVE WITH OUR VELOCITY OF LEARNING?
}

\author{
Nuno Álvaro Ferreira Rodrigues \\ Faculty of Psychology and Educational Sciences, University of Coimbra, Portugal \\ xeurekax@hotmail.com
}

\begin{abstract}
Alexander Kovacec
Faculty of Science and Technology, University of Coimbra, Portugal

kovacec@mat.uc.pt
\end{abstract}

Ana Cristina Ferreira de Almeida

Faculty of Psychology and Educational Sciences, University of Coimbra, Portugal

calmeida@fpce.uc.pt

\begin{abstract}
Aвstract: Learning and use of what is learned is not restricted to school. But, besides knowledge, will and management skills are necessary to reach the pace. The social implementation of the intellectual booty highlights the mathematical mastery of the population, so that knowledge of mathematics should be an integral part of an individual and an educational priority. Although it is true that the construction and consolidation of knowledge happens throughout life, adolescence is undoubtedly one of the most important and sensitive periods, anticipating further capacity building. In Portugal, the results obtained by students in the national exams are, on average, bellow the expected. Unfortunately, educational reforms implemented over the past decades have not solved this problem. How can we motivate students to devote time and energy to the study of mathematics now for their future success? Which strategies catalyze good performances for lifelong learning? Heuristics! Our research project has started with a workshop for high school teachers at an Educational Center, in Coimbra, in 2011. Meeting sessions were devoted to mathematical problem solving supported by George Polya's model. Teachers were invited to apply this methodology to ninth grade students, through the 2011/2012 school year. In parallel with the tracking results by solving selected questions extracted from the International Mathematical Kangaroo competition, pupils had to answer a questionnaire about their attitudes towards Math and Problem Solving in the beginning and at the end of the school year. In this paper we explore the promise of learning Mathematics problem-based to shorten the distance between what we do not know and willingness to learn. This is a glimpse into mathematical problem solving practice in a time perspective.
\end{abstract}

Keywords: heuristics, mathematics, problem solving, time perspective.

\section{Once upon a time... a never ending story called Math}

Progress is built with knowledge resources and due to that mathematics is always under construction. As one more level is added to the structure we are in position to see far away 
and get a better conscious of the great beyond. If the tools used in this endeavor have become more sophisticated and efficient, it is also true that the effort made to place one more brick is undoubtedly greater.

Spread along Pregel River banks, Konigsberg city, in the $18^{\text {th }}$ century, was the center of a puzzling problem. In the course of History, for better mobility, there were built seven bridges and since then the inhabitants wondered about the possibility of walking on all, without recurrence. They tried to accomplish that goal but without success. Unable to find a solution, the mayor of Danzing asked Leonhard Euler, who lived at St. Petersburg, for help. The answer came swiftly.

"Thus you see, most noble Sir, how this type of solution bears little relationship to mathematics, and I do not understand why you expect a mathematician to produce it, rather than anyone else, for the solution is based on reason alone, and its discovery does not depend on any mathematical principle. Because of this, I do not know why even questions which bear so little relationship to mathematics are solved more quickly by mathematicians than by others."

(Hopkins \& Wilson, 2004)

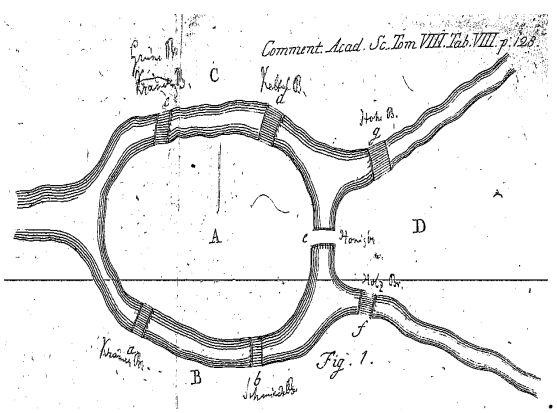

Figure 1

Despite Leonhard Euler's words, he realized that his reasoning, presented to the St. Petersburg Academy on August 26th, 1735, and originally published in 1741 (Figure 1) was a breakthrough in Math, starting a new branch today known as graph theory.

To explore the Konigsberg Seven Bridges Problem let's engage into George Pólya four steps problem solving model.

What does the problem say?

Challenge the reader to travel along Konigsberg seven bridges without repetition, establishing a network between banks and two islands in the river bed.

Is more information regarding the problem statement available?

Yes. The $18^{\text {th }}$ century Konigsberg city map.

Are there restrictions regarding the place where the path should start?

No. The travel can begin on the coast or in any one of the small islands.

After some attempts is the pathway revealed? 
No. Under the problem restrictions it appears to be missing always a bridge.

How can we represent the problem?

Symbolize the north, south and both islands by points and each bridge by a line (Figure 2).

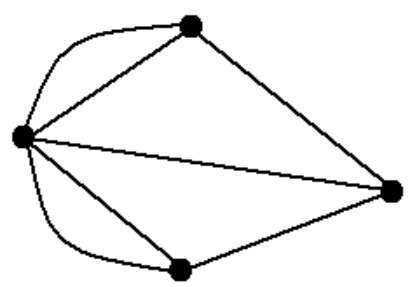

Figure 2

Does the diagram exhibit data that has not yet been analyzed?

Yes. It allows identifying, in a clear way, the number of bridges connected to each point (Figure 3).

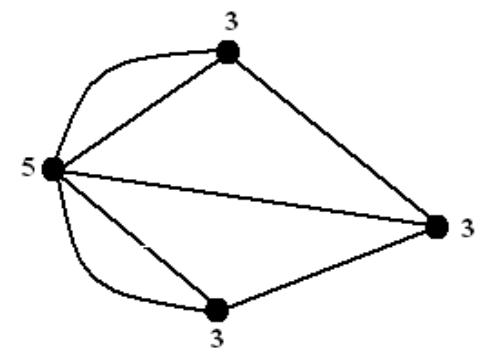

Figure 3

To arrive and depart, the place must be connected to bridges, in even number. If all dots are connected to even number of segments, then the tour can begin and end in the same place (circuit). If all dots are linked to even number of segments, except two, the route (path) is also possible, and it starts and ends in place with odd number.

Is it possible to do a circuit?

No, to accomplish that goal all locations should be linked to even number of bridges.

Is it possible to do a path?

No, because to accomplish that goal all locations, with the exception of departure and arrival, should be connected with an even number of bridges.

The problem has no solution! What happens if one bridge is withdrawn?

Regardless the bridge subtracted it is always possible to complete a path. 
The Konigsberg Seven Bridges Problem was quickly solved but in Math that doesn't always happen. Pierre de Fermat, in his copy of the book Arithmetic from Diophantus, wrote, around 1637, in the margin, next to the sum of squares problem, that , with $n$ greater than two, and $x, y, z, n$ positive integers, didn't have solution. Unfortunately, in his words, he couldn't write the proof there due to the lack of space.

Since then he has no more revisited the subject. After Pierre de Fermat's death in 1665, the son, Clément-Samuel Fermat, has published in 1670, a new edition from Arithmetic with his father's notations. For more than three hundred years professional and amateur mathematicians tried to demonstrate Pierre de Fermat statement, all without success, despite some major progress made in the $19^{\text {th }}$ and $20^{\text {th }}$ century. Then, on June, $23^{\text {rd }} 1993$ Andrew Wiles announced at the Conference of Sir Isaac Newton Institute for Mathematical Sciences, in Cambridge, the most wanted proof to Fermat's Last Theorem, so called because all the remaining observations of the French mathematician had already been demonstrated. Later, inaccuracies were found, but Andrew Wiles didn't give up and returned to work on his proof, accomplished his goal, then published on 1995 Annals of Mathematics.

"Perhaps I could best describe my experience of doing mathematics in terms of entering a dark mansion. Because, when one goes into the first room and it's dark, completely dark one stumbles around bumping into the furniture, gradually you learn where each piece of furniture is, and finally after six months or so you find the light switch, you turn it on, suddenly it's all illuminated, you can see exactly where you were."

(Singh \& Lynch, 1996)

For $n$ equal to one there is an infinity number of solutions. Replacing $n$ by two it is still possible to solve the problem. Solutions $(x, y, z)$, such as $(3,4,5)$, are called Pythagorean triple, numbers that fulfill the equation. Fermat's Last Theorem is an expansion of this problem with $n$ integer, greater than two.

"I never use a computer. I sometimes might scribble, I do doodles, I start trying to find patterns really, so I'm doing calculations which try to explain some little piece of mathematics and I'm trying to fit it in with some previous broad conceptual understanding of some branch of mathematics. Sometimes that'll involve going and looking up in a book to see how it's done there, sometimes it's a question of modifying things a bit, sometimes doing a little extra calculation, and sometimes you realize that nothing that's ever been done before is any use at all, and you just have to find something completely new and it's a mystery where it comes from."

(Singh \& Lynch, 1996)

Introduced to Fermat's Last Theorem at age of ten, since then Andrew Wiles was amazed with the statement and his open ended demonstration, "I had this very rare privilege of being able to pursue in my adult life what had been my childhood dream." (Singh \& Lynch, 1996). We can argue about how to unlock hard problems. The master key is study with method, acquired by experience, throughout time, only then it is possible to become expertise in the Art of Problem Solving.

Today, the Goldbach's Conjecture is one of the greatest mathematical challenges to human intelligence. Until now no one has been capable to prove that all even number, 
greater that two can be written as sum of two prime numbers. The quest began on 1742 with a letter from Christian Goldbach to Leonhard Euler and despite important steps forward, it remains open ended. Resilience is essential to overcome difficulties, as control, beliefs, resources and heuristics are to establish connections between different issues.

Theoretical models put into practice give us a better understanding of the complex mechanisms engaged to produce learning.

\section{Problem Solving in a Time Perspective Framework}

After this review, throughout the History of Mathematics, concerning problems with different temporal horizon perspectives demanding specific knowledge and reasoning, complex psychological activities and resilience, the authors anticipate that structural changes only come with time. If Problem Solving is shaped by metacognition processes that can be self-regulate allowing autonomy and learning with significance it is also true that cognitive achievements are formed by motivational aspects. The conceptions, attitudes, and expectations of the students regarding mathematics and mathematics teaching are considered to be very significant underlying school experience and achievement (Schoenfeld A. , 1985).

Throughout 2011 last trimester the authors conducted Heuristics in Math Teaching - Tools for Problem Solving, a fifty hour course to high school teachers at Nova Ágora Educational Center, in Coimbra. In parallel to the workshop, participants were invited to collaborate in an exploratory study focused on ninth grade students' attitudes towards mathematics and their performances concerning mathematical problem solving. Why the focus on them? Because ninth grade students are less than one year far away from starting Secondary Education, a moment when they need to make curricular options with future consequences, both academic and professional. In 2011/2012 school year more than one in four students from ninth grade didn't accomplish success in Math.

Behaviors are consequences of each one's motivations. In a social cognitive perspective, motivation is conceived as a dynamic process with interactions between subject and context regarding individual experiences and perceptions.

With the purpose to identify what explains pupils' attitudes, and their influence, towards Math Problem Solving, the authors have put into practice a questionnaire to be answered by students at the beginning and at the end of school year.

For each question pupils had to choose one of four options of agreement about the degree felt as true to him/herself with the respective statement: Very Much, More or Less, Sometimes and Not Really, scoring 3, 2, 1 and 0 points in $Q_{1}, Q_{2}, Q_{3}, Q_{4}, Q_{5}, Q_{6}, Q_{7}, Q_{8}$, $Q_{9}, Q_{12}, Q_{16}, Q_{17}, Q_{18}, Q_{19}$ and 0,1,2 and 3 points in the remaining items, inversing the scores in the desirable sense, viewed as the attitudes more prompt for successful learning and problem solving.

Questions from the International Mathematical Kangaroo have been selected to compare students' performances, in distinct moments. Despite the original multiple choice model, the authors have decided not to present options. In the first term, pupils have been exposed to thirty questions, eighteen more twelve, forty five minutes each, with increasing difficulty level. After data analysis, authors have determined that further tests would only comprehend ten questions, six more four, forty five minutes each. Students replied to 
two tests in this design throughout second school term and one in the third term. For investigation purposes the first group of questions has only been considered due the lack of answers concerning problems with great difficulty level. Each answer scores 0 (Blank / Nonsense), 1 (Weak reasoning), 2 (Miss solution due to a minor error), 3 (Correct solution without justification), 4 (Correct solution with justification), 5 (Correct solution with original procedures).

Table 1 - Items of the Attitudes toward Mathematical Problem Solving Scale conceived for this study

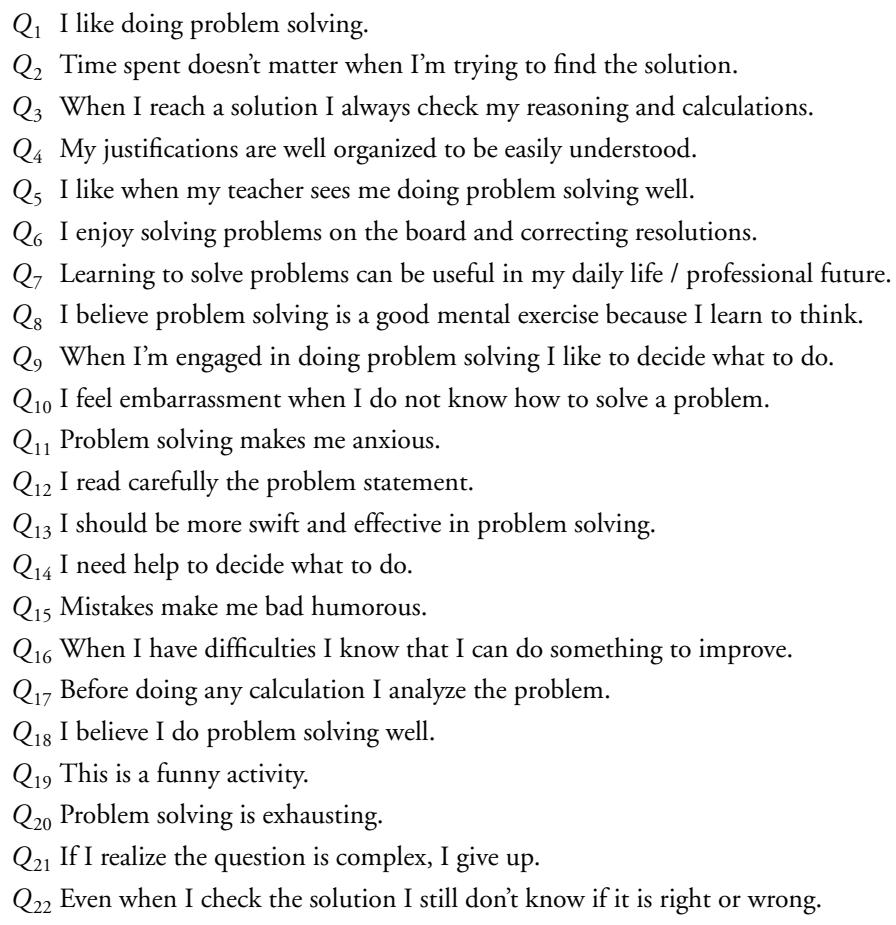

All data was organized with SPSS ${ }^{1}$ tools. Statistics concerning the questionnaire and International Mathematical Kangaroo performances balanced with school year results have help to build a sketch about students' interests and aptitudes.

Educational Psychology dealing with dynamic models, when applied to Problem Solving, combine human factor with the straight laws of Math, giving a chance to extract both content and procedure information for fostering development and learning.

\footnotetext{
${ }^{1}$ Statistical Package for the Social Sciences.
} 


\section{Thoughts sustained by results}

Is mathematics a difficult subject for all students around the globe? PISA ${ }^{2}$ outcomes tell us that the answer is no. On average, North European pupils score better results. Why does that happen? What do they have that others don't? Let's reformulate the question. What don't they have that Southern countries got plenty? One straight answer is warm weather and many sunny hours. As emphasized before, Time plays an important role in the process of understanding and doing Math. Why will I stay quietly closed among four walls with my math textbook as companion if outside pleasure calls for me? If in the past I was not able to achieve success in problem solving activity, today I'm certainly doom to failure. Cultural heritage is a not negligible factor. It is not by chance, that the Portuguese word Fado doesn't have translation into English. It expresses the idea of destiny embraced in past, present or future pessimism. As a metaphor Portugal still waits the return of Sebastian I, the young king vanished in the 1578 Alcácer Quibir battle. Portuguese greatest achievements are perpetuated in History books, but present and future are waiting to new chapters to be written.

Time five dimensions, Past-Negative, Past-Positive, Present-Hedonistic, Present-Fatalistic and Future-Oriented (Zimbardo \& Boyd, 2009) shape people's choices. A Past-Negative perception combined with a Present-Hedonistic attitude jeopardizes a Future-Oriented perspective related Math. Today adolescents have at their disposal an almost infinite number of gadgets, mobile phones with Internet, video games consoles and hundreds of TV channels. All those instruments are attractive, colorful, entertaining, ready to consume, in opposition to pupils' awareness about Math. A more appealing curriculum, put into practice with vividly lessons may hold students attention, but regarding speed it's impossible to go over stages if we want to consolidate and apply knowledge far from routine exercises. Feedback can be quite different among adolescents; those that are Future-Oriented engage and extract, in principle, more from problem solving work than Present-Oriented kids, although the last ones understand the value of mathematical knowledge in their professional and social future. Perseverance, a main factor in problem solving activity, doesn't find much echo among Present-Hedonistic individuals.

In Problem Solving the outcome is only a fraction of the procedure and its significance depends on the question under analysis. Since year 2005 ninth grade students have to do a national final exam. First year results where catastrophic! On average, more than seven upon ten students scored insufficient. To face this chaos, in 2006, the government has started a plan of action with two main vectors: educational courses to teachers and more hours allocated to Mathematics. Since then results have balanced between mediocre and acceptable (Figure 4), due to a set of reasons, namely the exam difficulty level, students/ parents/teachers/school dedication, curricular organization, or most likely, all those aspects, and others, combined.

The apparent slow progress helps to answer why the distance between what we know and what we don't know is always beyond of what we can achieve with our velocity of learning, concerning mathematical understanding.

\footnotetext{
${ }^{2}$ Program for International Student Assessment, focus on 15-years-old students to evaluate capacities in reading literacy, mathematics literacy and science literacy.
} 


\section{Ninth Grade National Final Exam - Students Positive Results (\%)}

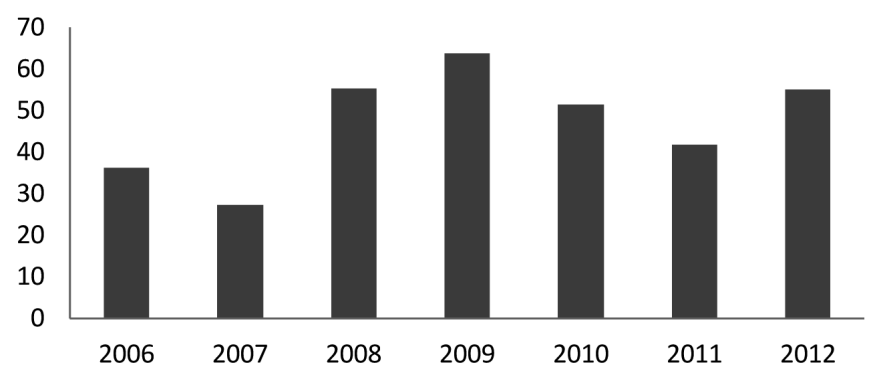

Figure 4

Expertise only comes with time and dedication. If techniques can be hard to master, Problem Solving goes beyond because it requires a more deep thinking. In Math, simplicity and complexity sustain each other as two faces of one coin.

Problem A: What is the value to $13+24+35+46+57+68+79 ?^{3}$

Problem B: What is the value to $x-y$, if $x=\ldots$ and $y=13+24+35+20112013 ?^{4}$

The previous questions regard number theory but if the first is straightforward, and in appearance, without significance, the last one connects knowledge base, heuristic procedures, metacognition and beliefs (Schoenfeld, 2011, pp. 3-4), a course of action that has been in the genesis of Heuristics in Math Teaching - Tools for Problem Solving, a workshop with eighteen high school teachers' participants.

The authors have conducted a study during 2011/2012 school year with a sample composed by 96 youngsters, ninth school year old students, 55 females $(54,2 \%)$ and 44 males $(45,8 \%)$ from seven classes, in six public schools from urban areas in the district of Coimbra. The questionnaire regarding problem solving attitudes attends to Schoenfeld model, aiming the assessment of heuristics, resources, control and beliefs. In a global scale,

\footnotetext{
${ }^{3}$ In a cut way process student adds the eight parcels. Is he able to use a more efficient strategy, less susceptible to computational error and capable to generate the solution in the shortest time? To do so pupils must have mathematical sensitivity, quality that comes from practice. From the problem analysis emerges that pairs of numbers at the same distance from the extremes generate equal result. From this pattern solution becomes easy to get: 101 $+101+101+101=4 \times 101=404$.

${ }^{4}$ What should we do after reading a question difficult to solve? As a marathon racer, problem solving is done step by step, the number of stages used and time needed to accomplish the goal depends on the complexity of the matter and the problem solver's skills.

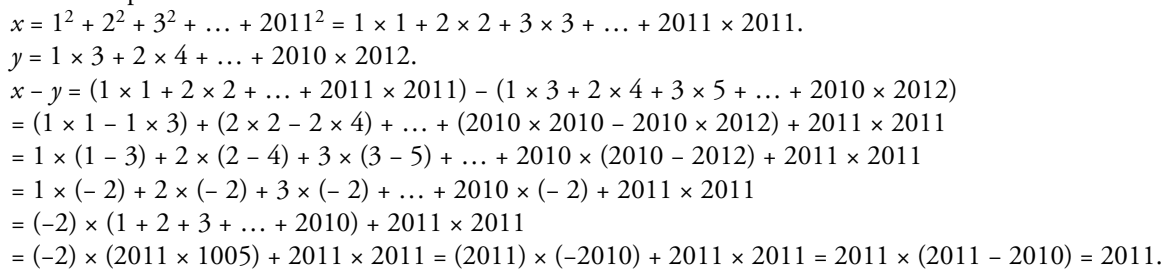


concerning first term, data reveals 0,787 Cronbach's Alpha internal consistency, when missing values are replaced by the trend.

All items score relevant in the SPSS Item-Total Statistics chart. KMO and Bartlett's Test (Table 2) results put on view conditions to perform a factorial analysis.

Table $2-K M O$ and Bartlett's Test

\begin{tabular}{|l|c|c|}
\hline \multicolumn{2}{|c|}{ Kaiser-Meyer-Olkin Measure of Sampling Adequacy. } &, 758 \\
\hline Bartlett's Test of Sphericity & Approx. Chi-Square & 764,732 \\
\hline & df & 231 \\
\hline & Sig. &, 000 \\
\hline
\end{tabular}

An exploratory factorial analysis was conducted to determinate the most appropriate dimensional structure for the given data set. Exploratory factor analysis was performed using the principal components method (PCA) and Oblimin rotation with the Statistical Program for Social Sciences (SPSS 20®).

The initial results show that the first six components explain approximately $64 \%$ of all the variance and each item displays a significant saturation level. Factors have been labeled regarding the structure matrix data and attending to the theoretical model of Schoenfeld (Table 3).

Table 3 - Factorial structure of the Scale used to assess Attitudes towards Mathematical Problem Solving

\begin{tabular}{|c|c|c|}
\hline Factors & Factor Labels & Items \\
\hline$F_{1}$ & Beliefs/Motivation & $\left(Q_{1}, Q_{2}, Q_{7}, Q_{8}, Q_{9}, Q_{18}, Q_{19}\right)$ \\
\hline$F_{2}$ & External Control & $\left(Q_{13}, Q_{14}, Q_{22}\right)$ \\
\hline$F_{3}$ & Mood & $\left(Q_{10}, Q_{11}, Q_{15}\right)$ \\
\hline$F_{4}$ & Resources & $\left(Q_{20}, Q_{21}\right)$ \\
\hline$F_{5}$ & Heuristics & $\left(Q_{3}, Q_{4}, Q_{12}, Q_{16}, Q_{17}\right)$ \\
\hline$F_{6}$ & Knowledge Exhibition & $\left(Q_{5}, Q_{6}\right)$ \\
\hline
\end{tabular}

The reliability statistics for each subscale, concerning Cronbach's Alpha, have scored Beliefs/Motivation (0,832), Control (0,615), Mood (0,732), Resources (0,645), Heuristics $(0,738)$ and Knowledge Exhibition (0,383).

Which correlations can be established between factors and the global scale? Statistic data allows identifying multiple connections that underline the complexity of behaviors in 
relation to Math Problem Solving. Answers to first term questionnaire put on display a set of those unions, namely, Beliefs/Motivation - Resources, Beliefs/Motivation - Heuristics, Beliefs/Motivation - Knowledge Exhibition, Control - Mood, Control - Resources, Mood - Resources, Heuristics - Knowledge Exhibition. Each one of the six factors is significantly correlated with the total scale.

It is not by chance that Beliefs/Motivation is such a powerful instrument; it captures the idea of success $v$ s. failure and perseverance $v$ s. renounce, engaging theoretical understanding, tools to do Problem Solving and the will in showing the work done to others. Control skills are linked to disposal and knowledge, undoubtedly the lack of aptitude to deal with emotions can be the source of bad humor, as metacognition helps to organize, open and use what is inside the shelves of information. When I understand what to do I like to do it! The good use of heuristics seems to give confidence allowing the student to share his reasoning with the teacher or colleagues.

Table 4 - Correlation coefficients between each factor and the total scale

\begin{tabular}{|c|c|c|c|c|c|c|c|}
\hline & $F_{1}$ & $F_{2}$ & $F_{3}$ & $F_{4}$ & $F_{5}$ & $F_{6}$ & Total Scale \\
\hline F1 & & --- & & & & &, $752^{* *}$ \\
\hline F2 &, 096 & --- & & & & &, $324^{* *}$ \\
\hline F3 &, 027 &, $303^{* *}$ & --- & & & &, $467^{* *}$ \\
\hline F4 &, $292^{* *}$ &, $285^{* *}$ &, $293^{* *}$ & --- & & &, $454^{* *}$ \\
\hline F5 &, $383^{* *}$ &,- 135 &,- 010 &, 075 & --- & &, $566^{* *}$ \\
\hline F6 &, $316^{* *}$ &,- 063 &, 054 &,- 019 &, $397^{* *}$ & -- &, $490^{* *}$ \\
\hline
\end{tabular}

**. Correlation is significant at the 0.01 level (2-tailed).

Months later, in the course of school year last term, students have been exposed to the same questionnaire. Will there be changes? If so, in what way and why did they occur?

The rank chart allows understanding variations regarding students' attitudes concerning the components presented previously. Surprisingly, or not, in all of them, more pupils have scored worse at the end of school year comparing to those who have increased their performance. The major differences are related to Heuristics, Control and Resources.

The Mean Rank values are found after all data from both questionnaires, related to each component, have been assembled into one column. Then, positions are established from the highest to the lowest and split in two groups, identified as Negative Ranks and Positive Ranks, to compute each one's mean. Despite their progress regarding Beliefs/ Motivation and Knowledge Exhibition, students still display inferior Mean Rank. About Control, Mood, Resources and Heuristics the Mean Rank of those who have improved is quite better comparing with the group that has presented worse results in the last term. This seems to underline that it is easier to see progress regarding Beliefs/Motivation and Knowledge Exhibition attitudes in students that initially didn't reveal them, and it is most likely that steps forward concerning Control, Mood, Resources and Heuristics can be done more swiftly among those who were already imbued with them in the first term.

A Wilcoxon test, which evaluates difference between medians, was applied to this repeated-measure design in order to estimate if participants have changed their attitudes. 
About the whole sample, Test Statistics (Table 5) results show significant differential concerning Control; first term $(\mathrm{m}=1.19, \mathrm{sd}=0,55) /$ third term $(\mathrm{m}=1.04, \mathrm{sd}=0,40)$, Mood; first term $(\mathrm{m}=1.78, \mathrm{sd}=0,86)$ / third term $(\mathrm{m}=1.60, \mathrm{sd}=0,76)$, Resources; first term $(\mathrm{m}=1.50, \mathrm{sd}=0,76) /$ third term $(\mathrm{m}=1.27, \mathrm{sd}=0,64)$ and Heuristics; first term $(\mathrm{m}=2.21$, $s d=0,48) /$ third term $(m=2.05$, sd $=0,49)$.

Table 5 - Test Statistics ${ }^{a}$

\begin{tabular}{|c|c|c|c|c|c|c|}
\hline & $\begin{array}{c}F_{1} 3^{\text {rd }} \text { Term } \\
- \\
F_{1} 1^{\text {st }} \text { Term }\end{array}$ & $\begin{array}{c}F_{2} 3^{\text {rd }} \text { Term } \\
- \\
F_{2} 1^{\text {st }} \text { Term }\end{array}$ & $\begin{array}{c}F_{3} 3^{\text {rd }} \text { Term } \\
- \\
F_{3} 1^{s t} \text { Term }\end{array}$ & $\begin{array}{c}F_{4} 3^{\text {rd }} \text { Term } \\
- \\
F_{4} 1^{\text {st }} \text { Term }\end{array}$ & $\begin{array}{c}F_{5} 3^{\text {rd }} \text { Term } \\
- \\
F_{5} 1^{s t} \text { Term }\end{array}$ & $\begin{array}{c}F_{6} 3^{r d} \text { Term } \\
- \\
F_{6} 1^{\text {st }} \text { Term }\end{array}$ \\
\hline Z &,$- 320^{\mathrm{b}}$ & $-2,589^{b}$ & $-2,215^{\mathrm{b}}$ & $-2,780^{\mathrm{b}}$ & $-2,758^{\mathrm{b}}$ &,$- 995^{\mathrm{b}}$ \\
\hline Asymp. Sig. (2-tailed) & ,749 & 010 & 027 & 005 &, 006 & ,320 \\
\hline
\end{tabular}

a. Wilcoxon Signed Ranks Test

b. Based on positive ranks.

The results concerning each one of the six teachers and the seven classes are showed below.

Table 5a - Test Statistics ${ }^{a, b}$

\begin{tabular}{|l|c|c|c|c|c|c|}
\hline & $\begin{array}{c}F_{1} 3^{r d} \text { Term } \\
- \\
F_{1} 1^{\text {st }} \text { Term }\end{array}$ & $\begin{array}{c}F_{2} 3^{\text {rd }} \text { Term } \\
- \\
F_{2} 1^{\text {st }} \text { Term }\end{array}$ & $\begin{array}{c}F_{3} 3^{\text {rd }} \text { Term } \\
-\end{array}$ & $\begin{array}{c}F_{3} 3^{\text {st }} \text { Term } \\
\text { rd Term }\end{array}$ & $\begin{array}{c}F_{5} 3^{\text {rd }} \text { Term } \\
-\end{array}$ & $\begin{array}{c}F_{6}{ }^{\text {std }} \text { Term } \\
-\end{array}$ \\
\hline Z & $-2,140^{c}$ &,$- 223^{c}$ & $-1,309^{c}$ & $-2,046^{c}$ & $-2,228^{c}$ &,$- 035^{c}$ \\
\hline Asymp. Sig. (2-tailed) &, 032 &, 823 &, 190 &, 041 &, 026 &, 972 \\
\hline
\end{tabular}

a. Teacher $=$ MAS

b. Wilcoxon Signed Ranks Test

c. Based on positive ranks.

Table 5b - Test Statistic ${ }^{a, b}$

\begin{tabular}{|c|c|c|c|c|c|c|}
\hline & $\begin{array}{c}F_{1} 3^{\text {rd }} \text { Term } \\
- \\
F_{1} 1^{\text {st }} \text { Term }\end{array}$ & $\begin{array}{c}F_{2} 3^{r d} \text { Term } \\
- \\
F_{2} 1^{s t} \text { Term }\end{array}$ & $\begin{array}{c}F_{3} 3^{\text {rd }} \text { Term } \\
- \\
F_{3} 1^{s t} \text { Term }\end{array}$ & $\begin{array}{c}F_{4} 3^{\text {rd }} \text { Term } \\
- \\
F_{4} 1^{s t} \text { Term }\end{array}$ & $\begin{array}{c}F_{5} 3^{\text {rd }} \text { Term } \\
- \\
F_{5}{ }^{s t} \text { Term }\end{array}$ & $\begin{array}{c}F_{6} 3^{r d} \text { Term } \\
- \\
F_{6} 1^{s t} \text { Term }\end{array}$ \\
\hline Z & $-1,442^{c}$ & $-1,915^{\mathrm{c}}$ &,$- 132^{c}$ &,$- 351^{\mathrm{d}}$ &,$- 305^{c}$ & $-1,064^{\mathrm{c}}$ \\
\hline Asymp. Sig. (2-tailed) & 149 &, 055 & 895 &, 726 &, 761 & ,287 \\
\hline
\end{tabular}

a. Teacher $=\mathrm{CMM}$

b. Wilcoxon Signed Ranks Test

c. Based on positive ranks.

d. Based on negative ranks. 
Table 5c - Test Statistics ${ }^{a, b}$

\begin{tabular}{|c|c|c|c|c|c|c|}
\hline & $\begin{array}{c}F_{1} 3^{\text {rd }} \text { Term } \\
- \\
F_{1} 1^{\text {st }} \text { Term }\end{array}$ & $\begin{array}{c}F_{2} 3^{\text {rd }} \text { Term } \\
- \\
F_{2} 1^{s t} \text { Term }\end{array}$ & $\begin{array}{c}F_{3} 3^{\text {rd }} \text { Term } \\
- \\
F_{3} 1^{\text {st }} \text { Term }\end{array}$ & $\begin{array}{c}F_{4} 3^{\text {rd }} \text { Term } \\
- \\
F_{4} 1^{\text {st }} \text { Term }\end{array}$ & $\begin{array}{c}F_{5} 3^{\text {rd }} \text { Term } \\
- \\
F_{5} 1^{s t} \text { Term }\end{array}$ & $\begin{array}{c}F_{6} 3^{\text {rd }} \text { Term } \\
- \\
F_{6} 1^{\text {st }} \text { Term }\end{array}$ \\
\hline $\mathrm{Z}$ &,$- 154^{c}$ &,$- 470^{c}$ & $-1,118^{c}$ &,$- 862^{c}$ & $-1,292^{\mathrm{c}}$ & $-1,656^{c}$ \\
\hline Asymp. Sig. (2-tailed) & ,878 & ,639 & ,264 & ,389 & , 196 & 098 \\
\hline
\end{tabular}

a. Teacher $=\mathrm{CMN}$

b. Wilcoxon Signed Ranks Test

c. Based on positive ranks.

Table 5d - Test Statistics ${ }^{a, b}$

\begin{tabular}{|c|c|c|c|c|c|c|}
\hline & $\begin{array}{c}F_{1} 3^{\text {rd }} \text { Term } \\
- \\
F_{1} 1^{s t} \text { Term }\end{array}$ & $\begin{array}{c}F_{2} 3^{\text {rd }} \text { Term } \\
- \\
F_{2} 1^{s t} \text { Term }\end{array}$ & $\begin{array}{c}F_{3} 3^{\text {rd }} \text { Term } \\
- \\
F_{3} 1^{\text {st }} \text { Term }\end{array}$ & $\begin{array}{c}F_{4} 3^{\text {rd }} \text { Term } \\
- \\
F_{4} 1^{s t} \text { Term }\end{array}$ & $\begin{array}{c}F_{5} 3^{\text {rd }} \text { Term } \\
- \\
F_{5} 1^{s t} \text { Term }\end{array}$ & $\begin{array}{c}F_{6} 3^{r d} \text { Term } \\
- \\
F_{6} 1^{s t} \text { Term }\end{array}$ \\
\hline $\mathrm{Z}$ &,$- 893^{c}$ & $-1,802^{c}$ &,$- 627^{c}$ & $-1,527^{c}$ & $-2,210^{c}$ &,$- 702^{c}$ \\
\hline Asymp. Sig. (2-tailed) & ,372 & 072 &, 531 &, 127 & ,027 & ,483 \\
\hline
\end{tabular}

a. Teacher $=$ MMF

b. Wilcoxon Signed Ranks Test

c. Based on positive ranks.

Table 5e - Test Statistics ${ }^{a, b}$

\begin{tabular}{|c|c|c|c|c|c|c|}
\hline & $\begin{array}{c}F_{1} 3^{\text {rd }} \text { Term } \\
- \\
F_{1} 1^{s t} \text { Term }\end{array}$ & $\begin{array}{c}F_{2} 3^{r d} \text { Term } \\
- \\
F_{2} 1^{s t} \text { Term }\end{array}$ & $\begin{array}{c}F_{3} 3^{\text {rd }} \text { Term } \\
- \\
F_{3} 1^{s t} \text { Term }\end{array}$ & $\begin{array}{c}F_{4} 3^{\text {rd }} \text { Term } \\
- \\
F_{4} 1^{s t} \text { Term }\end{array}$ & $\begin{array}{c}F_{5} 3^{\text {rd }} \text { Term } \\
- \\
F_{5} 1^{s t} \text { Term }\end{array}$ & $\begin{array}{c}F_{6} 3^{r d} \text { Term } \\
- \\
F_{6} 1^{s t} \text { Term }\end{array}$ \\
\hline $\mathrm{Z}$ & $-2,322^{c}$ &,$- 666^{\mathrm{d}}$ &,$- 000^{e}$ &,$- 378^{c}$ &,$- 677^{c}$ & $-1,983^{c}$ \\
\hline Asymp. Sig. (2-tailed) &, 020 &, 506 & 1,000 & ,705 & ,498 &, 047 \\
\hline
\end{tabular}

a. Teacher $=$ MIG

b. Wilcoxon Signed Ranks Test

c. Based on negative ranks.

d. Based on positive ranks.

e. The sum od negative ranks equals the sum of positive ranks.

Table $5 f-$ Test Statistics ${ }^{a, b}$

\begin{tabular}{|c|c|c|c|c|c|c|}
\hline & $\begin{array}{c}F_{1} 3^{\text {rd }} \text { Term } \\
- \\
F_{1} 1^{\text {st }} \text { Term }\end{array}$ & $\begin{array}{c}F_{2} 3^{\text {rd }} \text { Term } \\
- \\
F_{2} 1^{\text {st }} \text { Term }\end{array}$ & $\begin{array}{c}F_{3} 3^{\text {rd }} \text { Term } \\
- \\
F_{3} 1^{s t} \text { Term }\end{array}$ & $\begin{array}{c}F_{4} 3^{\text {rd }} \text { Term } \\
- \\
F_{4} 1^{s t} \text { Term }\end{array}$ & $\begin{array}{c}F_{5} 3^{\text {rd }} \text { Term } \\
- \\
F_{5} 1^{s t} \text { Term }\end{array}$ & $\begin{array}{c}F_{6} 3^{r d} \text { Term } \\
- \\
F_{6} 1^{s t} \text { Term }\end{array}$ \\
\hline Z & $-1,429^{c}$ & $-2,047^{d}$ & $-1,134^{\mathrm{d}}$ & $-1,136^{\mathrm{d}}$ & $-1,207^{d}$ & $-000^{e}$ \\
\hline Asymp. Sig. (2-tailed) &, 153 & 041 & 257 & ,256 & ,227 & 1,000 \\
\hline
\end{tabular}

a. Teacher $=\operatorname{MFM}(\mathrm{A})$

b. Wilcoxon Signed Ranks Test

c. Based on negative ranks.

d. Based on positive ranks.

e. The sum od negative ranks equals the sum of positive ranks. 
Table 5g - Test Statistics ${ }^{a, b}$

\begin{tabular}{|c|c|c|c|c|c|c|}
\hline & $\begin{array}{c}F_{1} 3^{\text {rd }} \text { Term } \\
- \\
F_{1} 1^{\text {st }} \text { Term }\end{array}$ & $\begin{array}{c}F_{2} 3^{r d} \text { Term } \\
- \\
F_{2} 1^{s t} \text { Term }\end{array}$ & $\begin{array}{c}F_{3} 3^{\text {rd }} \text { Term } \\
- \\
F_{3} 1^{s t} \text { Term }\end{array}$ & $\begin{array}{c}F_{4} 4^{3 d} \text { Term } \\
- \\
F_{4} 1^{s t} \text { Term }\end{array}$ & $\begin{array}{c}F_{5} 3^{\text {rd }} \text { Term } \\
- \\
F_{5} 1^{s t} \text { Term }\end{array}$ & $\begin{array}{c}F_{6} 3^{\text {rd }} \text { Term } \\
- \\
F_{6} 1^{\text {st }} \text { Term }\end{array}$ \\
\hline Z &, $000^{c}$ &,$- 600^{d}$ & $-1,556^{\mathrm{e}}$ & $-2,047^{\mathrm{e}}$ &,$- 594^{\mathrm{e}}$ & $-1,543^{\mathrm{e}}$ \\
\hline Asymp. Sig. (2-tailed) & 1,000 & ,549 & 120 & 041 & ,553 & ,123 \\
\hline
\end{tabular}

a. Teacher $=\operatorname{MFM}(\mathrm{B})$

b. Wilcoxon Signed Ranks Test

c. The sum od negative ranks equals the sum of positive ranks.

d. Based on negative ranks.

e. Based on positive ranks.

Is it odd that values have declined even with the Heuristics in Math Teaching - Tools for Problem Solving intervention program? Let's look for clues that can help answering that question.

Since early ages most Portuguese students start developing negative behaviors concerning Math due to causes previously exposed in this paper. When they arrive to ninth grade, prejudice concerning this subject has developed and spread deep roots on learning soil. Regardless of teachers' guidance into Math Problem Solving, that influence is limited because there is a curricular program to accomplish and limited time to do it. On May $10^{\text {th }}$ 2012, students did a national in-between exam before school year national final exam. The ninth grade school population scored, on average, the mediocre result of $31 \%$. Few weeks later, on June $21^{\text {st }} 2012$, 93435 students did the national exam, now with a medium score of $53 \%$.

If an image can be worth for a thousand words, these numbers are sufficient to illustrate, but not to understand, how complex is the teaching and learning process related to mathematical contents.

\section{Last appointments and first conclusions open to discussion}

Math comprehension only came with time. Literature about Problem Solving highlights methodologies that can be used to improve performances; still it is not one Lapis Philosophorum. A solid resources package is half way done to achieve success, as embodied on teacher CMM students' results during 2011/2012 school year, where the results are positively correlated with International Mathematical Kangaroo questions (Table 6). Last term students' school results are the outcome from the national in-between exam and not from regular internal tests as in the first and second term. This might explain why the correlation value extracted between IMK and SSR in the third term $(0,365)$ is not as strong as those observed in first and second term.

The way students engage themselves on Math Problem Solving is the result of multiple components. How to solve them is a never ending journey into cognition fields. 
Table 6 - Correlation Matrix between IMKe SSR*

\begin{tabular}{|c|c|c|c|c|}
\hline & $\begin{array}{c}I M K \\
1^{s t} \text { Term }\end{array}$ & $\begin{array}{c}I M K \\
2^{\text {nd }} \text { Term A }\end{array}$ & $\begin{array}{c}I M K \\
2^{\text {nd }} \text { Term B }\end{array}$ & $\begin{array}{c}I M K \\
3^{\text {rd }} \text { Term }\end{array}$ \\
\hline SSR 1 ${ }^{\text {st }}$ Term &, 559 &, 493 &, 690 &, 480 \\
\hline SSR 2 ${ }^{\text {nd }}$ Term &, 529 &, 267 &, 782 &, 294 \\
\hline SSR 3 $3^{\text {rd }}$ Term &, 444 &, 447 &, 809 &, 365 \\
\hline
\end{tabular}

\section{REFERENCES}

Hopkins, B., \& Wilson, R. J. (2004). The Truth about Königsberg. The College Mathematics Journal,35(3), 198-207.

SCHOenfeld, A. H. (2011). How we think: a theory of goal-oriented decision making and its educational applications. New York: Routledge.

Schoenfeld, A. (1985). Mathematical Problem Solving. Orlando, FL: Academic Press.

Singh, S., \& Lynch, J. (Directors). (1996). Fermat's Last Theorem [Movie].

Zimbardo, P., \& Boyd, J. (2009). The Time Paradox - The New Psychology of Time That Can Change Your Life. New York: Free Press. 